\title{
STRATEGI PROMOSI KEBUN RAYA UNMUL SAMARINDA TERHADAP TINGKAT KUNJUNGAN WISATAWAN
}

\author{
Rinto Dwiatmojo $^{\text {I, }}$ Said keliwar ${ }^{2}$, I Wayan Sudarmayasa ${ }^{3,}$ Anton Nurcahyo ${ }^{4}$, Isransyah Nor ${ }^{5}$

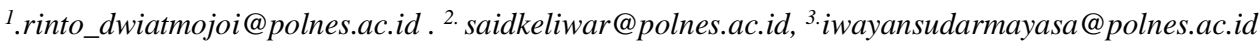 \\ 4.antonnurcahyo@polnes.ac.id;5.isransyahnor@yahoo.com \\ 1,2,3,4 Jurusan Pariwisata Politeknik Negeri Samarinda, Alamat, Kota Samarinda 75131, Indonesia \\ Jl. DR. Ciptomangunkusumo, Kampus Gunung Lipan, Samarinda, Kalimantan Timur, Indonesia 75131 \\ | Hot line: PABX (+62541) 260588, FAX: (+62541) 260355 \\ 5 , Guru SMKN 3 Berau \\ Jalan Derawan Tanjung Batu Derawan Berau
}

ARTICLE INFO

Article history:

Received 2 Feb 2019

Revised 1 April 2019

Accepted 5 Juni 2019

\section{Mengajukan ISSN}

Keywords: promotion mix, strategic, Tourist
ABSTRACT

Kebun Raya Unmul Samarinda sebagai salah satu destinasi tujuan wisata yang berada di Samarinda, Kalimatan Timur memfungsikan sebagai tempat memelihara, membina vegetasi dan memperbanyak keanekaragaman flora jenis-jenis eksotik, tempat penelitian, tempat pendidikan lingkungan hidup dan berperanan sebagai areal rekreasi alam (Ekowisata). Sebagai salah satu destinasi unggulan di Samarinda KRUS berusaha agar tetap diminati oleh para pengunjung, namu hal ini tidaklah mudah jika pemasaran yang dilakukan secara optimal terutama bagaimana mengkomunikasikannya kepada pengunjung. Penelitian ini betujuan untuk mengetahui strategi promosi yang tepat dalam rangka meningkatkan kunjungan wisatawan Kebun Raya Unmul Samarinda. Hasil penelitian merekomendasikan kepada pihak pengelola untuk tidak saja menggunakan promosi dari mulut ke mulut namun di bantu dengan menggunakan bauran promosi lainnya yang terdiri dari Advertising, Personal Selling, Publicity, dan Sales Promotion sebagai strategi promosi Kebun Raya Unmul samarinda.

Copyright (C) 2019 Politeknik Negeri Samarinda. All rights reserved.

\section{PENDAHULUAN}

Pariwisata merupakan suatu fenomena yang ditimbulkan dari kegiatan manusia yang melakukan perjalanan dari suatu tempat ke tempat lain. Dengan semakin meningkatnya kesejahteraan masyarakat hingga kebutuhanan untuk melakukan perjalanan wisata pun semakin meningkat. Hal ini sangat berpengaruh terhadap tingkat kunjungan wisatawan kesuatu objek daerah tujuan wisata. Kalimantan Timur sebagai salah satu propinsi yang memiliki potensi pariwisata yang dapat diandalkan dan sangat lengkap, sebagaian besar potensi wisata yang ada disediakan oleh alam Kalimantan. Kalimantan Timur memiliki kekayaan alam berupa hutan, flora \& fauna, sungai, jeram, keindahan laut dan didukung dengan budaya, adat istiadat serta wisata 
sejarah maupun objek wisata buatan untuk mendukung kepariwisataan di propinsi ini. Ketersediaan objek wisata alam yang disempurnakan dengan flora dan fauna didalammya di baur dengan budaya dan sejarah, serta dikemas dalam paket wisata ecotourism menjadikan Kalimantan Timur sebagai tempat tujuan wisata dan menempatkan posisinya pada segmen wisata minat khusus.

Objek wisata alam sangat potensial untuk dikelola dan dikembangkan dengan manajemen objek wisata yang baik. Peran yang sangat penting yang harus dilakukan adalah menetapkan suatu strategi promosi dan pengembangan yang tepat untuk memperkenalkan dan menarik minat kunjungan wisatawan domestik maupun manca negara kesuatu objek tujuan wisata alam. Hal ini perlu dilakukan karena persaingan antar objek tujuan wisata semakin ketat.Salah satu kawasan pariwisata khususnya objek wisata alam yang menjadi andalan propinsi Kalimantan Timur dan khususnya Samarinda sebagai ibu kota propinsi memiliki objek wisata alam Kebun Raya Unmul. Objek wisata alam ini mengandalakan potensi sumber daya alam dan ekosistemnya, baik dalam bentuk asli maupun perpaduan dengan buatan manusia.

Kebun Raya Unmul yang pada awalnya ditetapkan sebagai kawasan hutan konservasi dan difungsikan sebagai hutan pendidikan dan kebun botani bagi civitas akademik Universitas Mulawarman, memiliki potensi sumber daya alam yang menyajikan keindahan hutan dan kekayaan flora serta fauna didalamnya. Pada perkembangannya difungsikan pula sebagai obyek wisata dan rekreasi. Dengan pengembangan objek wisata KRUS baik dari segi sarana dan prasarana, diharapkan banyak wisatawan domestik maupun mancanegara berminat untuk datang berkunjung baik untuk berekreasi maupun melakukan penelitian. Untuk pencapaian tingkat kunjungan yang diharapkan maka pengelola perlu melakukan penetapan strategi pemasaran yang benar dan tepat, terutama pada penetapan strategi promosi untuk menjangkau wisatawan datang berkunjung ke kebun Raya Unmul.

Promosi merupakan bagian dari rangkaian kegiatan pemasaran, kegiatan ini sangat penting dilakukan sebagai alat komunikasi yang harus terus menerus dilakukan agar dapat mendekatkan diri dengan wisatawan, terutama dalam menetapkan strategi promosi mana yang paling efektif dalam meyebarkan informasi, membedakan serta mengunggulkan suatu produk ataupun jasa dibandingkan produk atau jasa lainnya, membentuk citra dimata wisatawan sesuai dengan yang diinginkan melalui alat - alat promosi sehingga tujuan dalam meningkatkan kunjungan wisatawan dapat terwujud.

\section{Metodologi Penelitian}

Penelitian ini menggunakan metode deskriptif kualitatif untuk menggali secara mendalam bagimana strategi promosi KRUS terhadap kunjungan wisatawan. Maka jenis penelitian yang digunakan adalah eksplorasi, dikarenakan penelitian ini bertujuan untuk mengetahui apa yang dikerjakan oleh orang orang dalam menangani masalah untuk kepentingan pembuatan 
rencana dan pengambilan keputusan dimasa depan. Data yang penulis peroleh kemudian di analisis dengan menggunakan metode SWOT.

\section{II.Landasan Teori}

Menurut Undang-Undang RI No. 9 Tahun 1990 tentang kepariwisataan,menyatakan bahwa pariwisata adalah kegiatan yang bertujuan menyelenggarakan jasa pariwisata, menyediakan atau mengusahakan obyek dan daya tarik wisata, usaha sarana pariwisata dan usaha lain yang terkait di bidang tersebut.

The World Tourism Organisation memberikan definisi Tentang Wisatawan ( tourist), sebagai :

"Any person residing within a country, irrespective of nationality, travelling to a place within this country other than his usual place of residence for a period of not less than 24 hours or one night for a purpose other than the exercise of a remunerated activity in the place visited. The motives for such travel may be: (1) leisure ( recreation, holidays, health, studies, religion, sports) ; (2) business, family, mission, or meeting."

Promosi pada hakekatnya
adalah suatu
pemunikaran, artinya aktifitas
pemasaran yang $\begin{array}{r}\text { berusaha } \\ \text { menyebarkan informasi, }\end{array}$
mempengaruhi/membujuk, dan
atau mengingatkan pasar sasaran
atas perusahaan dan produknya
agar bersedia menerima, membeli
dan loyal pada produk yang
ditawarkan perusahaan yang
bersangkutan,.

Tujuan dari perusahaan melakukan promosi menurut
Tjiptono (2001:221) adalah menginformasikan,

mempengaruhi dan membujuk serta meningkatkan pelanggan tentang perusahaan dan bauran pemasarannya.

Menurut Kotler (2001:98-100) Dalam melakukan promosi, agar efektif perlu adanya bauran pemasaran yaitu kombinasi optimal bagi berbagai jenis kegiatan atau pemilihan jenis kegiatan promosi yang paling efektif dalam meningkatkan penjualan, Ada 4 jenis kegiatan promosi, antara lain :

1. Periklanan (Advertising), yaitu bentuk promosi non personal dengan menggunakan berbagai media yang ditujukan untuk merangsang pembelian.

2. Penjualan Tatap Muka (Personal Selling), yaitu bentuk promosi secara personal dengan presentasi lisan dalam suatu percakapan dengan calon pembeli yang ditujukan untuk merangsang pembelian.

3. Publisitas (Publisity), yaitu suatu bentuk promosi non personal mengenai, pelayanan atau kesatuan usaha tertentu dengan jalan mengulas informasi/berita tentangnya (pada umumnya bersifat ilmiah).

4. Promosi Penjualan (Sales promotion), yaitu suatu bentuk promosi diluar ketiga bentuk diatas yang ditujukan untuk merangsang pembelian.

\section{Pembahasan}

Dari hasil analisis dengan menggunakan metode SWOT, direkomendasikan bagi pengelola 
Kebun Raya Unmul Samarinda dalam menetapkan strategi promosi yang akan dilakukannya dengan menggunakan saluran promosi lainnya selain menggandalkan promosi dari mulut ke mulut dan tidak menggandalkan dinas terkait lainnya dalam melakukan kegiatan promosi KRUS.

Namun lebih penting lagi bahwa pengelola harus dapat memahami apa yang diinginkan dan diminati oleh pengunjung sehingga apa yang menjadi tujuan KRUS dapat tercapai.

Berikut saluran Promosi yang dapat digunakan disesuaikan dengan karakteristik produk dan pasar KRUS :

\section{a. Advertaising/ Periklanan}

Dengan Iklan, maka dapat mengenalkan produk kepada konsumen jauh lebih luas terutama dengan bantuan media tehnologi, seperti membuat website selain berbiaya murah, jangka panjang dan dapat menjangkau masyarakat yang jauh lebih luas bahkan sampai mancanegara.

\section{b. Promosi Penjualan/ Sales Promotion}

Promosi penjualan dapat membantu meningkatkan penjualan dalam jangka waktu pendek, biasanya hanya selama kegiatan tersebut diselenggarakan. Pendekatan ini dapat dilakukan dengan menggundang pihak potensial untuk melakukan kegiatan yang diadakan pengelola pada destinasi tersebut.

\section{c. Hubungan Masyarakat/ Public Relation}

Dengan Humas dapat menciptakan citra positif KRUS, melalui beberapa aktivitas kegiatan diantaranya publisitas produk pada event - event yang diikutinya.

\section{d. Penjualan Perorangan / Personal Selling}

Melalui Penjualan perorangan ditujukan untuk memberikan keyakinan dan pengenalan produk yang lebih dalam kepada para konsumen. Berdasarkan penelitian pengunjung KRUS lebih didominasi oleh kalangan muda sehingga diharapkan pengelola dapat terjun langsung ke sekolah - sekolah untuk mengenalkan KRUS sebagai sarana pendidikan dan rekreasi.

\section{Kesimpulan}

Promosi adalah salah satu kegiatan pemasaran yang sangat penting dilakukan karena dengan cara ini destinasi dapat berkembang dengan pesat salah satunya melalui bauran promosi yakni periklanan, promosi penjualan, humas dan penjualan perorangan. Namun upaya melaksanakan kegiatan promosi harus diimbangi dengan pelayanan yang memuaskan agar pengunjung tetap akan datang mengunjungi Kebun Raya Unmul Samarinda.

\section{Daftar Pustaka}

David, Fred R. 2004. Manajemen Strategis Edisi Bahasa Indonesia. PT Indeks kelompok Gramedia, Jakarta.

Dinas Pariwisata kota Samarinda, 2011

Kotler, P, 2002. Pemasaran Perhotelan dan Kepariwisataan. 
Pearson Education Asia Pte, Ltd.

Dan PT Prenhallindo, Jakarta.

Yoeti, Oka. A. 1997. Pemasaran

Pariwisata, Angkasa, Bandung. 